\title{
Analisis Kualitas Terjemahan dari Bahasa Inggris ke dalam Bahasa Indonesia
}

\author{
Titis Surgawi13, Hermanu Joebagio ${ }^{14}$, Djono ${ }^{15}$ \\ titis.surgawi16@gmail.com
}

Abstract: Language is an important way of communicating with the people. Sometimes, the people in another place may feel difficult to understand what the meaning when they are talking with others. The way to catch and understand meaning is by translating it. Translation is the process of moving meaning from one language into another language. This research aims to explain the quality of translation of Garuda Magazine from English into Indonesian. The analysis concern on accuracy, clarity/clearness and naturalness of translation of Garuda Magazine from English into Indonesian. The research method uses qualitative descriptive and the type of research is content analysis. This research takes the segment "Welcome on Board" page 12 on Garuda Magazine in term November 2008 as source of data. The result of the research shows that 3 data (15,79\%) are less accurate translation and $84,21 \%$ or 16 sentences out of 19 sentences are accurate; 3 data (15,79\%) are less clear translation and 84, 21\% or 16 sentences out of 19 sentences are clear; $5,26 \%$ or 1 sentence out of 19 sentences is unnatural, $36,84 \%$ or 7 sentences out of 19 sentences are less natural and $57,90 \%$ or 11 sentences out of 19 sentences are natural.

Keywords: Translation, Quality of Translation

\footnotetext{
${ }^{13}$ Mahasiswa Magister Teknologi Pendidikan Universitas Sebelas Maret Surakarta

14 Dosen Universitas Sebelas Maret Surakarta

15 Dosen Universitas Sebelas Maret Surakarta
} 


\section{PENDAHULUAN}

$\mathrm{B}$

ahasa adalah cara penting berkomunikasi dengan orang lain. Orang-orang menggunakan bahasa untuk memberi tahu orang lain bagaimana perasaan mereka, apa yang mereka butuhkan, dan untuk bertanya. Terkadang, orang-orang di tempat lain mungkin merasa sulit untuk memahami apa artinya saat mereka berbicara dengan orang lain. Sehingga, mereka membutuhkan penerjemah untuk memahami artinya. Cara untuk memahami apa artinya adalah dengan menerjemahkan bahasa tersebut. Penerjemahan dapat didefinisikan sebagai proses pengalihan makna bahasa sumber ke dalam bahasa sasaran (Larson, 1984). Artinya penerjemahan adalah proses memindahkan makna dari satu bahasa ke bahasa lain. Bahasa yang diterjemahkan disebut bahasa sumber dan bahasa terjemahannya disebut bahasa sasaran.

Dalam penelitian ini, peneliti mencoba menganalisis kualitas terjemahan pada Majalah Garuda. Secara keseluruhan, peneliti perlu mengetahui kualitas terjemahan di majalah ini, apakah bisa dibaca, akurat dan alami atau tidak. Kualitas terjemahan bisa dilihat dari keterbacaan, keakuratan dan kealamiahannya. Larson (1984) menjelaskan bahwa terjemahan yang baik harus memenuhi tiga kriteria: akurasi, kejelasan/ keterbacaan dan kealamian. Dalam penelitian ini, peneliti ingin menganalisis kualitas terjemahan. Sehingga, rumusan masalah dalam penelitian ini adalah sebagai berikut: bagaimana keakuratan, kejelasan/ keterbacaan dan kealamiahan di segmen "Welcome on Board" halaman 12 pada Majalah Garuda bulan November 2008.

Pada umumnya, istilah penerjemahan mengacu pada perihal mengalihkan makna dari bahasa sumber ke dalam bahasa sasaran. Misalnya, seorang penerjemah menerjemahkan teks bahasa Inggris ke bahasa Indonesia. Ini berarti bahwa penerjemah mentransfer pesan dari bahasa sumber ke dalam bahasa sasaran, yaitu bahasa Inggris ke bahasa Indonesia. Bahasa Inggris sebagai bahasa sumber dan bahasa Indonesia sebagai bahasa sasaran.

Nida dan Taber (1969) berpendapat bahwa penerjemahan adalah proses menghasilkan makna setara dengan arti dan gaya mendekati bahasa sumber. Ini berarti bahwa penerjemah mencoba untuk menerjemahkan teks dengan makna dan gaya mendekati dengan bahasa sumber. Sementara Larson (1984) berpendapat bahwa terjemahan dalam menerjemahkan teks harus mempertimbangkan kosa kata, struktur gramatikal, situasi komunikasi dan konteks budaya dari bahasa sumber untuk mendapatkan terjemahan yang baik. Maka, pembaca dapat dengan mudah memahami makna yang diterjemahkan oleh penerjemah.

Proses penerjemahan adalah langkah-langkah atau tahapan-tahapan yang harus dilalui oleh penerjemah untuk menghasilkan produk terjemahan. Oleh karena itu, seorang penerjemah perlu berhatihati dalam melakukan kegiatan penerjemahan karena kesalahan dalam satu langkah akan menyebabkan kesalahan dalam langkah-langkah berikutnya. Jika hal itu terjadi, maka hasil terjemahan akan mengandung kesalahan. Nida dan Taber berpendapat bahwa ada tiga tahap dalam proses yaitu analisis (analysis), pengalihan (transferring) dan penyusunan kembali (restructuring). Kegiatan tersebut akan diuraikan sebagai berikut:

\section{Analisis}

Di dalam tahapan ini penerjemah dituntut untuk memahami isi, pesan atau makna teks bahasa sumber yang akan diterjemahkan secara utuh dan benar dengan cara membaca berulang-ulang dan mendetail untuk mendapatkan ide atau pesan dari teks sumber tersebut. Penerjemah juga harus menguasai bidang keilmuan dari teks sumber yang akan diterjemahkan.

\section{Pengalihan}

Pada tahap ini, penerjemah harus mampu mengalihkan isi pesan dari bahasa sumber ke dalam bahasa sasaran. Proses ini berlangsung di dalam otak penerjemah dan untuk menemukan padanan yang tepat maka penerjemah harus benar-benar berusaha menemukan padanan kata yang tepat sehingga hasil terjemahan pun baik. 


\section{Penyusunan kembali}

Setelah padanan kata ditemukan maka penerjemah harus menyusun kembali hasil terjemahannya ke dalam bahasa sasaran yang baik, tidak kaku, dan berterima. Penerjemah harus mampu menghasilkan terjemahan dengan nuansa yang sama seperti karangan asli, sehingga pembaca tidak merasa bahwa yang dibacanya itu adalah hasil terjemahan. Hal ini menunjukkan bahwa penggunaan bahasa sasarannya sudah wajar, tepat dan benar serta mudah dipahami oleh kelompok pembaca atau pengguna hasil terjemahan.

Satu hal yang harus diperhatikan dalam terjemahan adalah kriteria penerjemahan. Larson (1984) menyatakan bahwa ada tiga kriteria penerjemahan yang baik: keakuratan (accurate), kejelasan (clear) dan kealamiahan (naturalness). Kriteria tersebut akan dijelaskan sebagai berikut:

1. Keakuratan (accurate)

Memeriksa keakuratan adalah langkah penting yang harus dilakukan seorang penerjemah ketika melakukan penerjemahan. Dengan kata lain, ketepatan dalam mewakili makna teks asli dalam bahasa sasaran adalah tujuan utama dari penerjemah. Penerjemah harus hati-hati dan tetap memperhatikan makna teks asli serta struktur bahasa sasaran.

\section{Kejelasan (clear)}

Kriteria kedua penerjemahan yang baik adalah terkait dengan kejelasan. Kejelasan berfokus pada pesan seluruh hasil terjemahan harus mengungkapkan semua aspek makna dengan cara yang mudah dimengerti untuk para pembaca yang dituju.

3. Kealamiahan (naturalness)

Salah satu persyaratan utama dalam penerjemahan adalah bahwa terjemahan harus terkesan alami. Kealamiahan tergantung pada hubungan antara penulis dan pembaca dan topik atau situasi. Ini berarti bahwa untuk mengetahui terjemahan karya hasil/ penerjemahan apakah alami atau tidak, penerjemah harus memeriksa bentuk dan gaya bahasa yang digunakan dalam bahasa sasaran.

Nababan, Nuraeni dan Sumardiono (2012) berpendapat bahwa kriteria penerjemahan yang baik adalah sebagai berikut:

Tabel 1. Parameter Penilaian Keakuratan Terjemahan

\begin{tabular}{lcc}
\hline \multicolumn{1}{c}{ Parameter Kualitatif } & Skor & $\begin{array}{c}\text { Kategori } \\
\text { Terjemahan }\end{array}$ \\
\hline Makna kata, istilah teknis, frasa, klausa dan & 1 & Keakuratan rendah \\
kalimat atau teks bahasa sumber dialihkan & & \\
secara akurat ke dalam bahasa sasaran atau \\
dihilangkan
\end{tabular}


Tabel 2. Parameter Penilaian Keberterimaan Terjemahan

\begin{tabular}{lcc}
\hline \multicolumn{1}{c}{ Parameter Kualitatif } & Skor & Kategori Terjemahan \\
\hline Terjemahan tidak alamiah atau terasa seperti karya & 1 & Keberterimaan Rendah \\
terjemahan; istilah teknis yang digunakan tidak lazim & (Tidak Berterima) \\
bagi pembaca; frasa, klausa dan kalimat yang & \\
digunakan tidak sesuai dengan kaidah-kaidah & & \\
bahasa Indonesia. & & \\
\hline Pada umumnya terjemahan sudah terasa alamiah, & 2 & Keberterimaan sedang \\
namun ada sedikit masalah pada penggunaan istilah & & (Kurang Berterima) \\
teknis atau terjadi sedikit kesalahan gramatikal dan & & \\
kurang sesuai dengan kaidah-kaidah bahasa \\
Indonesia
\end{tabular}

Tabel 3: Parameter Penilaian Keterbacaan Terjemahan

\begin{tabular}{|c|c|c|}
\hline Parameter Kualitatif & Skor & Kategori Terjemahan \\
\hline $\begin{array}{l}\text { Terjemahan sulit atau bahkan sangat sulit dipahami } \\
\text { oleh pembacanya. }\end{array}$ & 1 & Keterbacaan Rendah \\
\hline $\begin{array}{l}\text { Pada umumnya terjemahan dapat dipahami oleh } \\
\text { pembaca; namun ada beberapa bagian yang harus } \\
\text { dibaca lebih dari satu kali untuk memahami } \\
\text { terjemahan tersebut. }\end{array}$ & 2 & Keterbacaan Sedang \\
\hline $\begin{array}{l}\text { Kata, istilah teknis, frasa, klausa dan bahkan kalimat } \\
\text { dalam terjemahan dapat dipahami dengan mudah } \\
\text { oleh pembacanya. }\end{array}$ & 3 & Keterbacaan Tinggi \\
\hline
\end{tabular}

\section{METODE PENELITIAN}

Penelitian ini merupakan penelitian kualitatif. Menurut Berg (2001), "Qualitative research thus refers to the meanings, concept, definition, characteristics, metaphor, symbols, and descriptions of things". Dengan kata lain, penelitian kualitatif adalah suatu teknik yang membahas makna, konsep, definisi, karakteristik, simbol dan deskripsi suatu benda. Dalam hal ini, peneliti membahas tentang makna yang terkandung di dalam dokumen tertulis yakni majalah. Peneliti menganalisis kualitas hasil terjemahan segmen "Welcome on Board" pada Majalah Garuda edisi bulan November 2008.

Teknik pengumpulan data dalam penelitian ini adalah menggunakan analisis konten. Menurut Berg (2009), "In content analysis, researcher examine artefact of social communications. Typically, these are written documents or transcription of recorded verbal communication". Dengan kata lain, teknik tersebut digunakan untuk meneliti konten dalam komunikasi sosial. Dalam hal ini, peneliti menggunakan analisis 
konten karena sumber datanya adalah dokumen tertulis yakni segmen "Welcome on Board" pada Majalah Garuda edisi bulan November 2008 halaman 12.

\section{HASIL DAN PEMBAHASAN}

Tabel 4. Tabel Persentase Akurasi

\begin{tabular}{clcc}
\hline No. & \multicolumn{1}{c}{ Kualitas terjemahan } & Jumlah (kalimat) & Persentase (\%) \\
\hline 1. & Akurat & 16 & 84,21 \\
\cline { 2 - 4 } 2. & Kurang akurat & 3 & 15,79 \\
\cline { 2 - 4 } 3. & Tidak akurat & - & - \\
\hline & & 19 & 100 \\
\hline
\end{tabular}

Tabel di atas menunjukkan beberapa kalimat hasil terjemahan sebanyak 16 kalimat $(84,21 \%)$ adalah akurat dan 3 kalimat $(15,79 \%$ ) adalah kurang akurat (nomor 12, 16 dan 18). Dalam penelitian ini, peneliti memberikan contoh kalimat bahasa sumber nomor 12 seperti yang dideskripsikan sebagai berikut:

SLT : Flying can dehydrate you, so drink of non-alcoholic liquid.

TLT : Berada di ketinggian dapat menyebabkan dehidrasi, sebaiknya Anda mengkonsumsi cukup minuman non-alkohol.

Berdasarkan Oxford Learner's Pocket Dictionary, kata "flying" mempunyai makna "move through the air as a bird does, or in an aircraft". Dan makna di dalam bahasa Indonesia berdasarkan An EnglishIndonesian Dictionary adalah "naik kapal terbang; terbang". Dalam SLT, penerjemah menerjemahkan kata "flying" menjadi "berada di ketinggian". Hal tersebut kurang akurat karena ada makna yang hilang dan tidak sesuai dengan konteksnya sehingga dapat mempengaruhi kesatuan pesan.

Tabel 5. Tabel Persentase Keterbacaan

\begin{tabular}{lccc}
\hline No. & Kualitas Terjemahan & Jumlah (kalimat) & Persentase (\%) \\
\hline & Jelas & 16 & 84,21 \\
\hline Kurang jelas & 3 & 15,79 \\
\hline Tidak jelas & - & - \\
\hline & 19 & 100 \\
\hline
\end{tabular}

Tabel di atas menunjukkan beberapa kalimat hasil terjemahan sebanyak 16 kalimat $(84,21 \%)$ adalah jelas dan 3 kalimat (15, 79\%) kurang jelas (nomor 1, 2 dan 15). Dalam penelitian ini, peneliti memberikan contoh nomor 1 seperti yang dideskripsikan sebagai berikut:

\section{SLT : Welcome aboard \\ TLT : Selamat Datang}

Berdasarkan Oxford Learner's Pocket Dictionary "aboard" berarti "on or in a ship, aircraft or train or a bus". Dan arti dalam bahasa Indonesia berdasarkan An English-Indonesian Dictionary adalah "di (atas, dalam); naik". Dalam SLT, penerjemah menerjemahkan "welcome on board" menjadi "selamat datang". Hal tersebut dirasa kurang jelas karena ada bagian tertentu yang harus dibaca lebih dari satu kali untuk 
membuat para pembaca paham dengan artinya. Akan lebih baik jika "welcome on board" diterjemahkan menjadi "selamat datang di penerbangan kami" karena sesuai dengan konteksnya yakni penerbangan.

Tabel 6. Tabel Persentase Kealamiahan

\begin{tabular}{|c|c|c|}
\hline Kualitas terjemahan & $\begin{array}{c}\text { Jumlah } \\
\text { (kalimat) }\end{array}$ & Persentase (\%) \\
\hline 1. Natural & 11 & 57,90 \\
\hline 2. Kurang natural & 7 & 36,84 \\
\hline 3. Tidak natural & 1 & 5,26 \\
\hline Total & 19 & 100 \\
\hline
\end{tabular}

Tabel di atas menunjukkan beberapa kalimat hasil terjemahan sebanyak 11 kalimat (57, 90\%) adalah natural, 7 kalimat (36, 84\%) kurang natural (nomor 3, 5, 10, 12, 13, 14 dan 16) dan 1 kalimat (5, $26 \%$ ) tidak natural (nomor 2). Dalam penelitian ini, peneliti memberikan contoh kalimat bahasa sumber nomor 3 seperti yang dideskripsikan sebagai berikut:

SLT : Do not leave valueables behind during transit stops and remember to check that you have all your belongings when you disembark.

TLT : Jangan meninggalkan barang-barang berharga selama transit dan disarankan untuk meneliti kembali barang bawaan Anda ketika akan meninggalkan pesawat.

Berdasarkan Oxford Learner's Pocket Dictionary, kata "check" berarti "make sure of something by examining or investigating; examining something to make sure it is correct, safe, satisfactory, etc". Dan artinya dalam bahasa Indonesia berdasarkan An English-Indonesian Dictionary berarti "mengirimkan", "menitipkan, menyimpan", "memeriksa". Dalam SLT, kata "check" diterjemahkan menjadi "meneliti". Hal ini kurang natural karena ada kesalahan grammatikal. Akan lebih baik jika penerjemah menerjemahkan "check" menjadi "memeriksa".

\section{KESIMPULAN}

a. Keakuratan segmen "Welcome on Board" Majalah Garuda edisi bulan November 2008

Dalam penelitian ini, ditemukan sebanyak $15,79 \%$ atau 3 kalimat dari 19 kalimat adalah kurang akurat. Hal tersebut terjadi karena ada makna yang hilang, sehingga dapat mempengaruhi kesatuan atau keutuhan pesan.

\section{b. Keterbacaan segmen "Welcome on Board" Majalah Garuda edisi bulan November 2008}

Dalam penelitian ini, ditemukan sebanyak $15,79 \%$ atau 3 kalimat dari 19 kalimat adalah kurang jelas. Hal tersebut terjadi karena hasil terjemahan dapat dengan mudah dipahami oleh pembaca tetapi ada bagian tertentu yang harus dibaca lebih dari satu kali untuk untuk memahami maknanya.

\section{c. Kealamiahan segmen "Welcome on Board" Majalah Garuda edisi bulan November 2008}

Dalam penelitian ini, ditemukan sebanyak $36,84 \%$ atau 7 kalimat dari 19 kalimat adalah kurang natural dan 5, 26\% atau 1 kalimat tidak natural. Hal tersebut terjadi karena ekuivalensi bahasa sasaran kurang sesuai. 


\section{SARAN}

Saran yang dapat diberikan di dalam penelitian ini adalah peneliti menyadari bahwa karya ini masih banyak kekurangan, tetapi peneliti berharap penelitian ini dapat berguna sebagai sumber referensi untuk peneliti lain yang tertarik untuk menganalisis kualitas terjemahan sebuah teks berbahasa Inggris.

\section{DAFTAR PUSTAKA}

Berg, B. L. (2009). Qualitative Research Methods For The Social Sciences (7th Ed). Boston: Pearson Education, Inc.

Larson, M. L. (1984). Meaning-Based Translation. Lanham: University Press of America, Inc

Machali, R. (2009). Pedoman Bagi Penerjemah: Panduan Lengkap Bagi Anda Yang Ingin Menjadi Penerjemah Profesional. Bandung: Kaifa

Miles, M. B., \& Huberman, A. M. (1984). Qualitative Data Analysis: A Sourcebook of New Methods. London: SAGE Publications

Nida, E. A., \&. Taber, C. R. (1969). The Theory and Practice of Translation. Leiden: E. J. Brill

Nababan, M. R., Ardiana, N., \& Sumardiono. (2012). Pengembangan Model Penilaian Kualitas Terjemahan. Kajian Linguistik dan Sastra, 24(1), pp. 39-57. 